\title{
Glaucous gull (Larus hyperboreus): a new bird record in Xinjiang, China
}

\author{
XIA Yong ${ }^{1,2}$, Paul HOLT ${ }^{3}$, WANG Yaotian ${ }^{4}$, GOU Jun ${ }^{4}$, CAI Xinbin ${ }^{5}$, WANG Chuanbo ${ }^{4}$, \\ DING Peng ${ }^{1,2 *}$, LIN Xuanlong ${ }^{4,5 *}$ \\ ${ }^{1}$ Xinjiang Key Laboratory of Environmental Pollution Monitoring and Risk Warning, Xinjiang Academy of Environmental \\ Protection Science, Urumqi 830011, China; \\ ${ }^{2}$ Junggar Ecological and Environmental Observation Station, Xinjiang Academy of Environmental Protection Science, Wujiaqu \\ 831304, China; \\ ${ }^{3}$ Sunbird, Bedfordshire SG 19 1DF, UK; \\ ${ }^{4}$ Xinjiang Bird Watching Society, Urumqi 830011, China; \\ ${ }^{5}$ Institute of Forest Ecology, Xinjiang Academy of Forestry, Urumqi 830063, China
}

\begin{abstract}
XIA Yong and WANG Yaotian saw a first-year glaucous gull (Larus hyperboreus) at Beihu Lake, Shihezi (a city of Xinjiang Uygur autonomous region; $44^{\circ} 22^{\prime} \mathrm{N}, 86^{\circ} 07^{\prime} \mathrm{E} ; 416 \mathrm{~m}$ asl) on 2 January 2016. The gull was also seen and photographed by other observers in the period of 19 December 2015 to10 January, 2016.
\end{abstract}

Keywords: Glaucous gull; Larus hyperboreus; first record; Shihezi; Xinjiang

Citation: XIA Yong, Paul HOLT, WANG Yaotian, GOU Jun, CAI Xinbin, WANG Chuanbo, DING Peng, LIN Xuanlong. 2016. Glaucous gull (Larus hyperboreus): a new bird record in Xinjiang, China. Journal of Arid Land, 8(5): 815-818. doi: $10.1007 / \mathrm{s} 40333-016-0093-9$

On 2 January 2016, XIA Yong and WANG Yaotian observed and photographed a suspicious first-year glaucous gull (Larus hyperboreus) at Beihu Lake, Shihezi, Xinjiang $\left(44^{\circ} 22^{\prime} \mathrm{N}, 86^{\circ} 07^{\prime} \mathrm{E}\right.$; $416 \mathrm{~m}$ asl). The gull was along with a group of mallard (Anas platyrhynchos) rather than mixed with other gulls. The bird was identified as a glaucous gull (L. hyperboreus) (MacKinnon et al., 2000; Svensson et al., 2009; Olsen and Larsson, 2004) through carefully matching the photographs (Figs. 1 and 2) with the relevant references. According to Ma (2011) and Zheng (2011), this was the first time the species recorded as a vagrant in Xinjiang.

Glaucous gull is a typical coastal bird with a length of $62-70 \mathrm{~cm}$, wing span of $138-160 \mathrm{~cm}$ and weight of 1.07-2.70 kg (Zhao, 2001; Brazil, 2009; Olsen and Larsson, 2004). The head, neck, underparts and tail of adult-birds are white while the mantle, back and wing coverts are light gray. In winter the head and neck of an adult-bird have some brown-patterning, which creates hooded appearance. However, a first-year glaucous gull retains most or all juvenile plumage in the first winter of its life. According to the photographs, we believe that the glaucous gull spotted in Shihezi was a first-year one. The gull was pale brown with neat brown pattern, pale and translucent flight feathers, and poorly marked tail. When standing, there is a contrast between the pale wing-tip and the darker body. The bird's head mark was not obvious and the dark eyes were circled with white eyelids. Glaucous gulls are different with similar large gulls such as glaucous-winged gull (L. glaucescens), and herring gull (L. argentatus). The wing-tips of glaucous gulls are paler than their rest part of wings (Zhao, 2001; Svensson et al., 2009; Olsen and Larsson,

\footnotetext{
"Corresponding author: DING Peng (E-mail: dpengde@126.com); LIN Xuanlong (E-mail: xuanlonglin@163.com) Received 2016-01-13; revised 2016-04-21; accepted 2016-05-13

(C) Xinjiang Institute of Ecology and Geography, Chinese Academy of Sciences, Science Pressand Springer-Verlag Berlin Heidelberg 2016
} 
2004; Ayé et al., 2012).

Glaucous gulls frequently appear in tundra, coasts, bays and islands in the Arctic regions during breeding seasons. They migrate south in winter and inhabit at coasts and fishing harbors. The species is occasionally found on the inland riverbanks during the migration (Olsen and Larsson, 2004; Ayé et al., 2012). They feed on fish, rats, insects, crustacean and mollusks as well as fledglings, eggs and animal organs (Zhao, 2001; Olsen and Larsson, 2004). During the observations, we found that the first-year glaucous gull ate mallard (Anas platyrhynchos), fish organs and hid the leftover food in water near the shore.

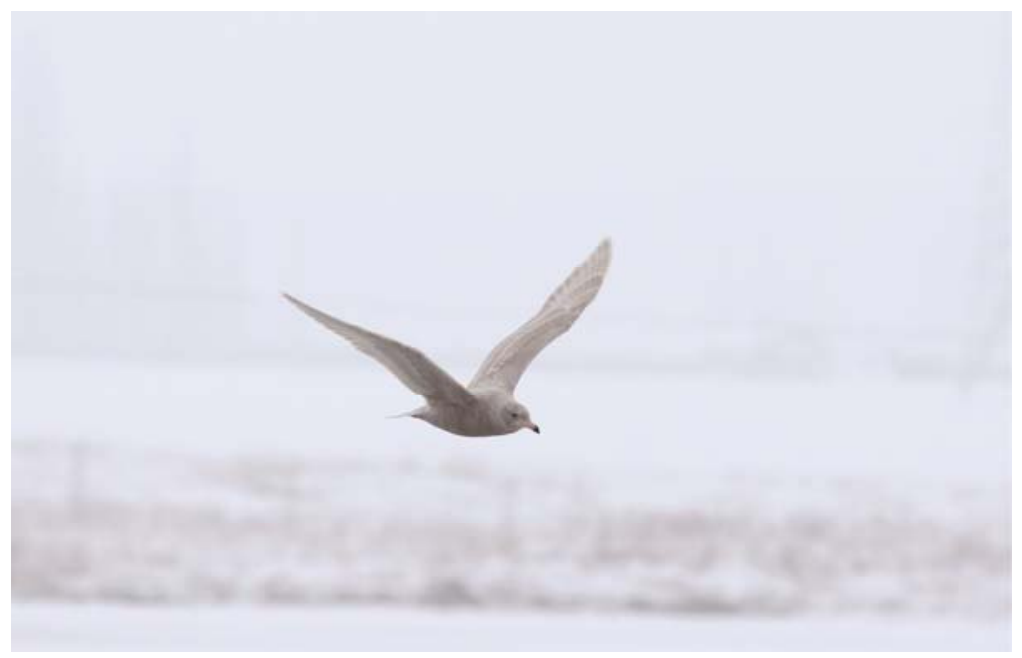

Fig. 1 Glaucous gull (Larus hyperboreus) at Beihu Lake in Shihezi on 2 January 2016 (The photo is provided by XIA Yong)

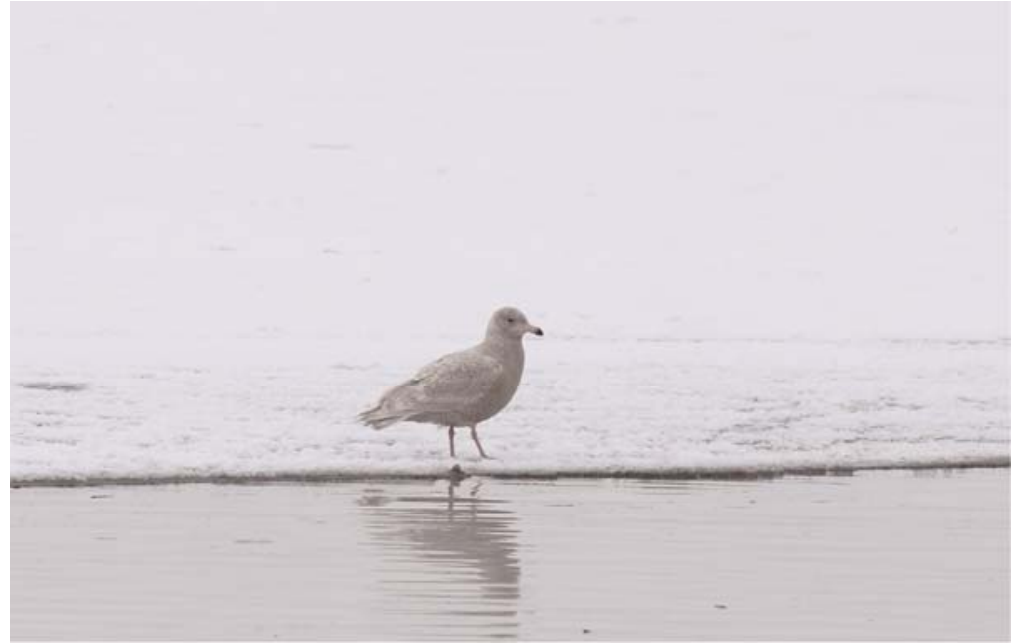

Fig. 2 Glaucous gull (L. hyperboreus) at Beihu Lake in Shihezi on 2 January 2016 (The photo is provided by XIA Yong)

Glaucous gulls breed in the Arctic coasts and islands of northern Eurasia and North America, and inhabit in the areas south of the Arctic Circle in winter. They are also found in the northeast, east and southeast coastal areas of China (Brazil, 2009; Zheng, 2011). Some individuals are observed as vagrants in Kazakhstan, Mongolia and the inland regions of Russia etc (Kalyakin and Voltzit, 2006; Wassink and Oreel, 2007; Bird Life International, 2015). Glaucous gulls are often overlooked in China. They are pretty rare spotted even in the coastal provinces. Table 1 presented the records of glaucous gulls in China according to bird reports and relevant references. Glaucous gulls were found in Jilin, Liaoning, Hebei, Tianjin, Shandong, Jiangsu and Shanghai, and accidentally observed in Beijing, Fujian, Guangxi, Xinjiang, Tibet, Hong Kong and Taiwan. 
Table 1 Records of glaucous gulls (Larus hyperboreus) in China

\begin{tabular}{|c|c|c|c|c|}
\hline & Site & $\begin{array}{c}\text { Date } \\
(\mathrm{mm} / \mathrm{yyyy})\end{array}$ & $\begin{array}{l}\text { Number } \\
\text { (individual) }\end{array}$ & Reference \\
\hline Beijing & Wild Duck Lake & $11 / 2011$ & $1\left(1^{\text {st }}\right.$-year $)$ & Nilsén Townshend $\left(2011^{*}\right)$ \\
\hline \multirow[t]{8}{*}{ Hebei } & \multirow[t]{6}{*}{ Beidaihe River } & $02 / 1917$ & 2 & La Touche $\left(1925-1934^{*}\right)$ \\
\hline & & $\begin{array}{l}03 / 1985 ; 09 / 1986 \\
10,11 / 1987\end{array}$ & $\begin{array}{l}3 \text { (ad. }) ; 2\left(1^{\text {st }}-\text { year }\right) ; 3 \\
\left(2^{\text {nd }}-\text { winter }\right) ; 1 \\
\left(3^{\text {rd }} \text {-year }\right)\end{array}$ & Holt et al. $\left(1989^{*}, 1994^{*}, 1997^{*}\right)$ \\
\hline & & $05 / 2004$ & 1 & Jannes $\left(2004^{*}\right)$ \\
\hline & & $05 / 2005$ & 1 & China Ornithological Society (2006) \\
\hline & & $03,04 / 2006$ & $\begin{array}{l}3 ; 2\left(2^{\text {nd }}-\text { winter }\right) ; 1 \\
\left(3^{\text {rd }} \text {-year }\right)\end{array}$ & Hornskov $\left(2006^{*}\right)$ \\
\hline & & $05 / 2011$ & 1 & China Coastal Water Bird Census Team (2015) \\
\hline & Happy Island & $05 / 1997$ & 1 (ad.) & Olsen and Larsson (2004) \\
\hline & Nanpu & $\begin{array}{l}04 / 2010 ; 04 / 2011 \\
04 / 2012 ; 04 / 2013\end{array}$ & 5 (ad.) & Slaymaker $\left(2010^{*}, 2011^{*}, 2012^{*}, 2013^{*}\right)$ \\
\hline \multirow[t]{3}{*}{ Jilin } & $\begin{array}{l}\text { Lower reaches of } \\
\text { Tumen River; }\end{array}$ & $\begin{array}{l}03,04 / 1988 ; 03 \\
04 / 1989\end{array}$ & $5-8$ & Yang et al. (1994) \\
\hline & \multirow[t]{2}{*}{ Jingxin, Huichun } & $03 / 2014$ & 3 & China Bird Report $\left(2014 a^{*}\right)$ \\
\hline & & $03 / 2016$ & $>50(30+$ ad. $)$ & Guan et al. $\left(2016^{*}\right)$ \\
\hline \multirow[t]{15}{*}{ Liaoning } & \multirow{3}{*}{$\begin{array}{l}\text { Shuangtaizi } \\
\text { Estuary Nature } \\
\text { Reserve, Panjin }\end{array}$} & 05/1991 & 1 (ad.) & Brazil (1992) \\
\hline & & $10 / 2001$ & 1 (ad.) & Holt P $\left(2001^{*}\right)$ \\
\hline & & $03 / 2015$ & 1 & China Bird Report $\left(2015 a^{*}\right)$ \\
\hline & \multirow[t]{2}{*}{$\begin{array}{l}\text { Yalu River } \\
\text { Wetland Nature } \\
\text { Reserve, Dandong }\end{array}$} & $\begin{array}{l}01,12 / 2005 ; \\
12 / 2006 ; 12 / 2007\end{array}$ & 5 & China Ornithological Society $(2006,2007)$ \\
\hline & & $04,05,10 / 2010$ & 3 & China Coastal Water Bird Census Team (2015) \\
\hline & \multirow[t]{2}{*}{ Zhuanghe Quay } & $01 / 2008 ; 01 / 2012$ & 4 (ad.) & Holt $\left(2008^{*}\right)$; Holt and Wang $\left(2008^{*}\right)$; Holt $\left(2012^{*}\right)$ \\
\hline & & $09 / 2010$ & 1 & China Coastal Water Bird Census Team (2015) \\
\hline & $\begin{array}{l}\text { Huanggui power } \\
\text { station }\end{array}$ & $01 / 2008$ & $\begin{array}{l}1\left(1^{\text {st }} \text {-year }\right) \\
1\left(2^{\text {nd }} \text {-winter }\right)\end{array}$ & Holt and Wang $\left(2008^{*}\right)$ \\
\hline & $\begin{array}{l}\text { Dalayaogang, } \\
\text { Zhuanghe }\end{array}$ & $03 / 2008$ & 1 (ad.) & Zhong et al. $\left(2008^{*}\right)$ \\
\hline & Jinzhou Bay & $03 / 2010$ & 1 (ad.) & China Bird Report $\left(2010 a^{*}\right)$ \\
\hline & Pikou, Dalian & $10 / 2011$ & $1\left(1^{\text {st }}\right.$-year $)$ & Beeke et al. $\left(2011^{*}\right)$ \\
\hline & Dalian Bay & $01 / 2012$ & $\begin{array}{l}1 \text { (ad. winter) } \\
2 \text { (ad.) }\end{array}$ & $\begin{array}{l}\text { Holt }\left(2012^{*}\right) \\
\text { Beeke and Holt }\left(2012^{*}\right) \text {; Holt and Townshend }\left(2012^{*}\right)\end{array}$ \\
\hline & $\begin{array}{l}\text { Jinzhou Bay } \\
\text { refuse dump }\end{array}$ & $01 / 2012$ & $\begin{array}{l}1\left(2^{\text {nd }}-\text { winter }\right) \\
1 \text { (ad. winter }) \\
1 \text { (ad.) }\end{array}$ & $\begin{array}{l}\text { Beeke and Holt }\left(2012^{*}\right) \\
\text { Holt }\left(2012^{*}\right) \\
\text { Holt and Townshend }\left(2012^{*}\right)\end{array}$ \\
\hline & $\begin{array}{l}\text { Maoyingzi } \\
\text { Landfill, Jinzhou }\end{array}$ & $02 / 2015$ & 1 & China Bird Report (2015b*) \\
\hline & Laotieshan cape & $09 / 2015$ & $1\left(2^{\text {nd }}\right.$-winter $)$ & Beeke et al. $\left(2015^{*}\right)$ \\
\hline \multirow[t]{5}{*}{ Shandong } & Shi Dao Wan & $10 / 1901$ & 1 & Jones (1911) \\
\hline & Chengshan island & $02 / 1902$ & 1 & Jones (1911) \\
\hline & Jiaozhou Bay & $01 / 2008$ & $1\left(1^{\text {st }}\right.$-year $)$ & Holt $\left(2008^{*}\right)$ \\
\hline & \multirow{2}{*}{$\begin{array}{l}\text { Laizhou Bay, } \\
\text { Laizhou }\end{array}$} & $12 / 2005 ; 02 / 2006$ & 4 & China Ornithological Society $(2006,2007)$ \\
\hline & & $11 / 2010$ & 2 & China Bird Report $\left(2010 b^{*}\right)$ \\
\hline Shanghai & $\begin{array}{l}\text { Shaweishan } \\
\text { Island }\end{array}$ & $05 / 1908$ & 1 & La Touche and Rickett (1912) \\
\hline \multirow[t]{2}{*}{ Tianjin } & \multirow{2}{*}{$\begin{array}{l}\text { HaibinYuchang, } \\
\text { Tanggu }\end{array}$} & $01 / 2004$ & $1\left(1^{\text {st }}\right.$-year $)$ & China Ornithological Society (2005) \\
\hline & & $02 / 2010$ & 1 & China Coastal Water Bird Census Team (2015) \\
\hline
\end{tabular}




\section{Acknowledgements}

This work was funded by the Innovation Fund of Xinjiang Academy of Environmental Protection Science (201410). We would like to thank Professor MA Ming and LIU Yang for their review and recommendations and also sincerely appreciate Mr. JIN Zuchang, Mr. XU Jie, Mr. QIN Yunfeng, Mr. GUAN Xiangyu, Mr. YANG Ye and Mr. LIN Dajing etc for submitting the record to China Bird Report.

\section{References}

Ayé R, Schweizer M, Roth T. 2012. Birds of Central Asia: Kazakhstan, Turkmenistan, Uzbekistan, Kyrgyzstan, Tajikistan, Afghanistan. Princeton: Princeton University Press, 138-139.

Bird Life International. 2015. Larus hyperboreus. The IUCN Red List of Threatened Species 2015: e.T22694343A85048979. [2016-04-14]. http://www.iucnredlist.org/details/22694343/0.

Brazil M A. 1992. The Birds of Shuangtaizihekou national nature reserve, Liaoning Province, P.R. China. Forktail, 7: 91-124.

Brazil M. 2009. Birds of East Asia: China, Taiwan, Korea, Japan, and Russia (Princeton Field Guides). London: Christopher Helm, 202-203.

Carey G J, Chalmers M L, Diskin D A, et al. 2001. The Avifauna of Hong Kong. Hong Kong: Hong Kong Bird Watching Society, 266-267.

China Coastal Water Bird Census Team. 2015. China Coastal Waterbird Census Report (Jan. 2010-Dec. 2011). Hong Kong: The Hong Kong Bird Watching Society, 14. (in Chinese)

China Ornithological Society. 2005. China Bird Report 2004. Beijing: China Ornithological Society, 94. (in Chinese)

China Ornithological Society. 2006. China Bird Report 2005. Beijing: China Ornithological Society, 132. (in Chinese)

China Ornithological Society. 2007. China Bird Report 2006. Beijing: China Ornithological Society, 154. (in Chinese)

Jones K H. 1911. On some birds observed in the vicinity of Wei Hai Wei, North-east China. Ibis 53(4): 657-695.

Kalyakin M V, Voltzit O V. 2006. ATLAS. Birds of Moscow City and the Moscow Region. Sofia-Moscow: Pensoft, 149.

La Touche J D, Rickett C B. 1912. A list of the species of birds collected and observed in the island of Shaweishan. Bulletin of the British Ornithologists' Club, 29: 124-160.

Liu X R, Ding Z S, Fang W H, et al. 2010. The Avifauna of Taiwan Vol. 2. Taipei: Forestry Bureau of the Taiwan Council of Agriculture, 294-295. (in Chinese)

Ma M. 2011. A Checklist on the Distribution of the Birds in Xinjiang. Beijing: Science Press, 1-186. (in Chinese)

MacKinnon J, Phillipps K, He F Q. 2000. A Field Guide to the Birds of China. Oxford: Oxford University Press, $166-167$.

Olsen K M, Larsson H. 2004. Gulls of Europe, Asia and North America. London: Christopher Helm, 187-203.

Svensson L, Mullarney K, Zetterström D. 2009. Collins Bird Guide: the most Complete Field Guide to the Birds of Britain and Europe ( $2^{\text {nd }}$ ed.). London: HarperCollins, 194-195.

Vaughan R E, Jones K H. 1913. The birds of Hong Kong, Macao, and the West River or Si Kiang in South-eastern China, with special reference to their nidification and seasonal movements.-Part II. Ibis, 55(2): 163-200.

Wassink A, Oreel G J. 2007. The Birds of Kazakhstan. Texel: De Cocksdorp, 111.

Wu J P, Lv Y L, Shu F, et al. 2015. Glaucous gull (Larus hyperboreus) found in Maizhokunggar county, Tibet, China. Chinese Journal of Zoology, 50(5): 820. (in Chinese)

Yang X J, Wu Z G, Cui G W. 1994. The rare vertebrate along the lower reaches of Tumen River. Chinese Journal of Zoology, 29(5): 42-46. (in Chinese)

Zhao Z J. 2001. A Handbook of the Birds of China. Changchun: Jilin Science and Technology Press, 551-552. (in Chinese)

Zheng G M. 2011. A Checklist on the Classification and Distribution of the Birds of China (2 $2^{\text {nd }}$ ed.). Beijing: Science Press, 96. (in Chinese)

Zhou F. 2011. A Checklist on the Distribution of Terrestrial Vertebrates of Guangxi. Beijing: China Forestry Publishing House, 82. (in Chinese) 